in vivo $34: 1195-1200(2020)$

doi:10.21873/invivo.11892

\title{
Influence of Preeclampsia on Induction of Labor at Term: A Cohort Study
}

\author{
JUTTA PRETSCHER ${ }^{1}$, CHRISTEL WEISS $^{2}$, ULF DAMMER $^{1}$, FLORIAN STUMPFE ${ }^{1}$, \\ FLORIAN FASCHINGBAUER ${ }^{1}$, MATTHIAS W. BECKMANN ${ }^{1}$ and SVEN KEHL ${ }^{1}$ \\ ${ }^{1}$ Department of Obstetrics and Gynecology, Erlangen University Hospital, Erlangen, Germany; \\ ${ }^{2}$ Department of Medical Statistics and Biomathematics, \\ University Medical Center Mannheim, Heidelberg University, Heidelberg, Germany
}

\begin{abstract}
Background/Aim: Even though vaginal delivery is a feasible option in patients with preeclampsia, the cesarean section rate in those patients is high. The aim of this study was to evaluate the influence of preeclampsia on induction of labor at term. Patients and Methods: This historical cohort study analyzed inductions of labor in women at term having preeclampsia versus women who were induced due to other reasons. The primary outcome measure was the cesarean section rate. Results: The cesarean section rate was higher in the preeclampsia group for both nulliparous and multiparous women after induction of labor but failed to reach statistical significane. The induction-to-delivery interval was longer in nulliparous women and the rate of vaginal birth within $48 \mathrm{~h}$ was lower in the nulliparous patiens with preeclampsia. However, the impact of preeclampsia on the cesarean section rate was not significant in the multivariable analysis following adjustment for BMI and parity. Conclusion: Preeclampsia at term did not influence the cesarean section rate in nulliparous and parous women when labor was induced.
\end{abstract}

Worldwide, $10 \%$ of all pregnancies are affected by some hypertension-associated complications. Preeclampsia occurs in $2-8 \%$ of all pregnancies with a fourfould higher risk of perinatal mortality $(1,2)$. The only curative treatment for

This article is freely accessible online.

Correspondence to: Jutta Pretscher, Erlangen University Hospital, Departement of Obstetrics and Gynecology, Universitätsstr. 21/ 23, D91054 Erlangen, Germany. Tel: +49 91318533553, Fax: +49 91318533552, e-mail: jutta.pretscher@uk-erlangen.de and Sven Kehl, Erlangen University Hospital, Departement of Obstetrics and Gynecology, Universitätsstr. 21/ 23, D-91054 Erlangen, Germany. Tel: +49 91318533553, Fax: +49 91318533552, e-mail: sven.kehl@ukerlangen.de

Key Words: Cesarean section, hypertension, induced labor, preeclampsia, term pregnancy. preeclampsia is induced delivery, which is indicated at 37 weeks of gestation at the earliest $(3,4)$. In cases of severe preeclampsia or if a severe growth restriction is diagnosed, clinicians should consider preterm delivery $(4,5)$.

The cesaerean section rate in cases of severe preeclampsia is high, in preterm pregnancies up to $70 \%$ or even more (6, 7). Even at term, many obstetricians prefer delivery by caesaerean section in women with preeclampsia, although this seems to be associated with a significant postpartum maternal morbidity (6). Since the neonatal outcome is not worsened following induction of labor compared to delivery via cesarean section, vaginal delivery is a feasible option (4, 7-9). Therefore, the aim of this study was to evaluate the influence of preeclampsia on labor induction at full-term (37 weeks or more).

\section{Patients and Methods}

This historical cohort study was undertaken at a single tertiary perinatal centre between 2011 and 2016. Women with labor induction at term were included. Exclusion criteria were: i) fetal breech position, ii) previous cesarean section, iii) multiple pregnancies, iii) intrauterine fetal death, and iv) structural or chromosomal fetal malformation. Furthermore, patients with premature rupture of membranes were excluded as it is known that it influences the success of labor (10). Patients with preeclampsia were compared to women who underwent induction of labor for other reasons. Preeclampsia was defined as blood pressure $\geq 140 / 90$ $\mathrm{mm} \mathrm{Hg}$ combined with either a proteinuria $>300 \mathrm{mg}$ total protein within a 24-h urine collection or a ratio of protein to creatinine $>30$ $\mathrm{mg} / \mathrm{mmol}$ (4). Ethical approval was given by the institutional review board of our university hospital (247_17 Bc). Informed consent was given by all participants.

Gestational age was determined from the last menstrual period and confirmed by or recalculated with biometric measurements obtained from fetal biometry during early pregnancy (according to current recommendations) (11). Before induction, the Bishop score was assessed by a midwife or a doctor (12). For labor induction, misoprostol (administered orally or vaginally), vaginal dinoproston gel, oxytocin, double-balloon catheter or a combination of these were used. Labor induction was continued until delivery. 
Table I. Baseline demographics and pregnancy characteristics.

\begin{tabular}{|c|c|c|c|}
\hline Characteristics & $\begin{array}{l}\text { Preeclampsia } \\
\text { group } \\
(\mathrm{n}=99)\end{array}$ & $\begin{array}{c}\text { No preeclampsia } \\
\text { group } \\
(n=1724)\end{array}$ & $p$-Value \\
\hline Age (years) & $31.1 \pm 6.2$ & $30.9 \pm 5.2$ & 0.6842 \\
\hline Height $(\mathrm{cm})$ & $166.8 \pm 6.7$ & $167.2 \pm 6.7$ & 0.6086 \\
\hline Weight $(\mathrm{kg})$ & $91.2 \pm 18.4$ & $85.0 \pm 17.0$ & 0.0004 \\
\hline Body mass index & $31.6 \pm 6.5$ & $29.6 \pm 5.9$ & 0.0011 \\
\hline Pregnancy & $1(1-7)$ & $1(1-12)$ & 0.1689 \\
\hline Parity & $0(0-5)$ & $0(0-5)$ & 0.0146 \\
\hline Gestational age (days) & $272.5 \pm 8.3$ & $283.8 \pm 8.0$ & $<0.0001$ \\
\hline Birth weight (grams) & $3,197.5 \pm 483.7$ & $3,492.9 \pm 499.6$ & $<0.0001$ \\
\hline Bishop score & $1(0-10)$ & $2(0-10)$ & 0.0088 \\
\hline Fetal growth restriction & $10(10.1 \%)$ & $104(6.0 \%)$ & 0.1040 \\
\hline $\begin{array}{l}\text { Placental insufficiency, } \\
\text { abnormal doppler (n, \%) }\end{array}$ & 0 & $22(1.3 \%)$ & 0.6283 \\
\hline $\begin{array}{l}\text { Gestational diabetes } \\
(\mathrm{n}, \%)\end{array}$ & $14(14.1 \%)$ & $258(15.0 \%)$ & 0.8230 \\
\hline $\begin{array}{l}\text { Intrahepatic cholestasis } \\
\text { of pregnancy }(\mathrm{n}, \%)\end{array}$ & $1(1.0 \%)$ & $23(1.3 \%)$ & 1.0000 \\
\hline \multicolumn{4}{|l|}{$\begin{array}{l}\text { Method of induction of } \\
\text { labour (first choice) }\end{array}$} \\
\hline Double-balloon catheter & $49(49.5 \%)$ & $903(52.4 \%)$ & 0.5725 \\
\hline Dinoproston (PGE 2) & $19(19.2 \%)$ & $160(9.3 \%)$ & 0.0013 \\
\hline Misoprostol (PGE 1) & $31(31.3 \%)$ & $646(37.5 \%)$ & 0.2160 \\
\hline Oxytocin & 0 & $14(0.8 \%)$ & 1.0000 \\
\hline
\end{tabular}

Quantitative data are presented as mean with standard deviation or as median (range) values. For qualitative factors, absolute and relative frequencies are given. $p<0.05$ was considered significant.

The primary outcome measure was the cesarean section rate Secondary outcome measures included i) the induction-to-delivery interval, ii) the rate of vaginal deliveries within 24 and $48 \mathrm{~h}$, iii) a failed labor induction (defined as no vaginal delivery within $72 \mathrm{~h}$ ), iv) neonatal outcome parameters, such as arterial umbilical cord $\mathrm{pH}$ and base excess, Apgar score after $5 \mathrm{~min}$, and postpartum admission to neonatal care unit, and v) maternal outcome parameter (chorioamnionitis).

All statistical calculations were performed using SAS, version 9.4 (SAS Institute Inc., Cary, NC, USA). For quantitative variables that were approximately following a normal distribution we calculated the mean value and standard deviation. For skewed, ordinal or quantitative discrete data we provide the median value together with minimum and maximum. Qualitative factors are presented by relative and absolute frequencies. Two mean values were compared using a 2 -sample $t$-test. For data that is not normally distributed we used the Mann Whitney $U$-test instead. For qualitative factors Chi2-test or Fisher's exact test were performed, as appropriate.

Furthermore, we performed a multivariable logistic regression analysis for the primary outcome measure "cesarean section rate" in order to analyse several variables simultaneously using the "forward selection" method. This technique enabled us to adjust for differences in baseline characteristics and potential confounders.

In general, the result of a statistical test was considered as significant if the $p$-Value was less than 0.05 .
Table II. Outcome parameters

\begin{tabular}{|c|c|c|c|}
\hline Outcome parameters & $\begin{array}{l}\text { Preeclampsia } \\
\text { group } \\
(\mathrm{n}=99)\end{array}$ & $\begin{array}{c}\text { No preeclampsia } \\
\text { group } \\
(\mathrm{n}=1724)\end{array}$ & $p$-Value \\
\hline \multicolumn{4}{|l|}{ Mode of delivery $(\mathrm{n}, \%)$} \\
\hline $\begin{array}{l}\text { Normal vaginal } \\
\text { delivery }\end{array}$ & $60(60.6 \%)$ & $1,167(67.7 \%)$ & 0.1439 \\
\hline $\begin{array}{l}\text { Surgical vaginal } \\
\text { delivery }\end{array}$ & $7(7.1 \%)$ & $175(10.2 \%)$ & 0.3201 \\
\hline Cesarean section & $32(32.3 \%)$ & $382(22.2 \%)$ & 0.0189 \\
\hline $\begin{array}{l}\text { Induction-Delivery- } \\
\text { Interval (min)* }\end{array}$ & $1,912(255-4,237)$ & $1,575(97-4,318)$ & 0.0051 \\
\hline $\begin{array}{l}\text { Vaginal delivery } \\
\text { within } 24 \mathrm{~h}(\mathrm{n}, \%)^{* *}\end{array}$ & $15(24.6 \%)$ & $504(31.1 \%)$ & 0.0226 \\
\hline $\begin{array}{l}\text { Vaginal delivery } \\
\text { within } 48 \mathrm{~h}(\mathrm{n}, \%)^{* *}\end{array}$ & $41(67.2 \%)$ & $1070(83.1 \%)$ & 0.0015 \\
\hline $\begin{array}{l}\text { Failed induction } \\
\text { (no delivery within } \\
72 \mathrm{~h} ; \mathrm{n}, \%)^{* *}\end{array}$ & $4(6.6 \%)$ & $68(5.3 \%)$ & 0.5625 \\
\hline Arterial umbilical $\mathrm{pH}$ & $7.278 \pm 0.078$ & $7.280 \pm 0.080$ & 0.7793 \\
\hline $\begin{array}{l}\text { Arterial umbilical } \\
\mathrm{pH}<7.05(\mathrm{n}, \%)\end{array}$ & 0 & $8(0.5 \%)$ & 1.0000 \\
\hline $\begin{array}{l}\text { Arterial umbilical } \\
\mathrm{pH}<7.10(\mathrm{n}, \%)\end{array}$ & $2(2.0 \%)$ & $23(1.3 \%)$ & 0.6430 \\
\hline $\mathrm{BE}<-12(\mathrm{n}, \%)$ & $1(1.0 \%)$ & $30(1.7 \%)$ & 1.0000 \\
\hline $\begin{array}{l}\text { Apgar score at } 5 \mathrm{~min} \\
<7(\mathrm{n}, \%)\end{array}$ & $2(2.0 \%)$ & $21(1.2 \%)$ & 0.3587 \\
\hline $\begin{array}{l}\mathrm{BE}<-12 \text { and Apgar score } \\
\text { at } 5 \min <7(\mathrm{n}, \%)\end{array}$ & 0 & $4(0.2 \%)$ & 1.0000 \\
\hline Abnormal CTG (n, \%) & $17(17.2 \%)$ & $306(17.7 \%)$ & 0.8836 \\
\hline Fetal blood analysis $(\mathrm{n}, \%)$ & $3(3.0 \%)$ & $40(2.3 \%)$ & 0.5047 \\
\hline Epidural anaesthesia (n, \%) & b) $37(37.4 \%)$ & $799(46.5 \%)$ & 0.0762 \\
\hline Oxytocin $(\mathrm{n}, \%)$ & $64(65.3 \%)$ & $717(42.3 \%)$ & 0.1403 \\
\hline $\begin{array}{l}\text { Meconium-stained } \\
\text { amniotic liquor (n, \%) }\end{array}$ & $17(17.2 \%)$ & $304(17.6 \%)$ & 0.9066 \\
\hline Chorioamnionitis $(\mathrm{n}, \%)$ & $1(1.0 \%)$ & $10(0.6 \%)$ & 0.4599 \\
\hline $\begin{array}{l}\text { Postpartum transfer to } \\
\text { neonatal care unit, total } \\
(\mathrm{n}, \%)\end{array}$ & $23(23.2 \%)$ & $268(15.6 \%)$ & 0.0423 \\
\hline $\begin{array}{l}\text { Infection of the newborn } \\
(\mathrm{n}, \%)\end{array}$ & $4(4.0 \%)$ & $85(5.1 \%)$ & 0.8149 \\
\hline
\end{tabular}

BE: Base excess; h: hours; CTG: cardiotocogram. *Cesarean sections and failed induction of labor are excluded. ${ }^{* *}$ Cesarean sections are excluded.

\section{Results}

In the investigated period there were 14,072 deliveries. Labor was induced in 3,148 women (22.4\%). After consideration of the inclusion and exclusion criteria, 1,823 cases were included in this study. There were 99 labor inductions for preeclampsia and 1,724 for other indications.

The demographic parameters are given in Table I. In the preeclampsia group, patients had a higher weight $(91.2 \pm 18.4$ $\mathrm{kg} v s .85 .0 \pm 17.0 \mathrm{~kg}, p=0.0004)$, as well as a higher a resulting body mass index (BMI in $\left.\mathrm{kg} / \mathrm{m}^{2}\right)(31.6 \pm 6.5 \mathrm{vs}$. 
Table III. Outcome parameters in nulliparous and parous women.

\begin{tabular}{|c|c|c|c|c|c|c|}
\hline \multirow[b]{2}{*}{ Outcome parameters } & \multicolumn{3}{|c|}{ Nulliparous } & \multicolumn{3}{|c|}{ Parous } \\
\hline & $\begin{array}{l}\text { Preeclampsia } \\
\text { group } \\
(\mathrm{n}=75)\end{array}$ & $\begin{array}{c}\text { No preeclampsia } \\
\text { group } \\
(\mathrm{n}=1088)\end{array}$ & $p$-Value & $\begin{array}{l}\text { Preeclampsia } \\
\text { group } \\
(n=24)\end{array}$ & $\begin{array}{c}\text { No preeclampsia } \\
\text { group } \\
(\mathrm{n}=636)\end{array}$ & $p$-Value \\
\hline \multicolumn{7}{|l|}{ Mode of delivery (n, \%) } \\
\hline Normal vaginal delivery & $40(53.3 \%)$ & $588(54.0 \%)$ & 0.9049 & $20(83 \%)$ & $579(91.0 \%)$ & 0.2664 \\
\hline Surgical vaginal delivery & $7(9.3 \%)$ & $155(14.2 \%)$ & 0.2346 & 0 & $20(3.1 \%)$ & 1.0000 \\
\hline Cesarean section & $28(37.3 \%)$ & $345(31.7 \%)$ & 0.3129 & $4(16.7 \%)$ & $37(5.8 \%)$ & 0.0550 \\
\hline Induction-Delivery-Interval (min)* & $2,261(582-4,237)$ & $1,767(288-4,318)$ & 0.0111 & $1,464(255-3,713)$ & $1,307(97-4,203)$ & 0.3426 \\
\hline Vaginal delivery within $24 \mathrm{~h}(\mathrm{n}, \%)^{* *}$ & $8(19.0 \%)$ & $203(28.4 \%)$ & 0.1893 & $7(36.8 \%)$ & $301(52.5 \%)$ & 0.1781 \\
\hline Vaginal delivery within $48 \mathrm{~h}(\mathrm{n}, \%) * *$ & $24(57.1 \%)$ & $571(79.9 \%)$ & 0.0005 & $17(89.5 \%)$ & $499(87.1 \%)$ & 1.0000 \\
\hline $\begin{array}{l}\text { Failed induction (no delivery within } \\
72 \mathrm{~h} ; \mathrm{n}, \% \text { )** }\end{array}$ & $4(9.5 \%)$ & $47(6.6 \%)$ & 0.5186 & 0 & $21(3.7 \%)$ & 1.0000 \\
\hline Arterial umbilical $\mathrm{pH}$ & $7.268 \pm 0.074$ & $7.276 \pm 0.081$ & 0.3649 & $7.311 \pm 0.082$ & $7.287 \pm 0.077$ & 0.1462 \\
\hline Arterial umbilical $\mathrm{pH}<7.05(\mathrm{n}, \%)$ & 0 & $7(0.6 \%)$ & 1.0000 & 0 & $1(0.2 \%)$ & 1.0000 \\
\hline Arterial umbilical $\mathrm{pH}<7.10(\mathrm{n}, \%)$ & $1(1.3 \%)$ & $20(1.8 \%)$ & 1.0000 & $1(4.2 \%)$ & $3(0.5 \%)$ & 0.1380 \\
\hline $\mathrm{BE}<-12(\mathrm{n}, \%)$ & $1(1.3 \%)$ & $21(1.9 \%)$ & 1.0000 & 0 & $9(1.4 \%)$ & 1.0000 \\
\hline Apgar score at $5 \min <7(\mathrm{n}, \%)$ & $2(2.7 \%)$ & $20(1.8 \%)$ & 0.6485 & 0 & $1(0.2 \%)$ & 1.0000 \\
\hline $\begin{array}{l}\mathrm{BE}<-12 \text { and Apgar score at } 5 \text { min } \\
<7(\mathrm{n}, \%)\end{array}$ & 0 & $4(0.4 \%)$ & 1.0000 & 0 & 0 & n. c. \\
\hline Abnormal CTG (n, \%) & $16(21.3 \%)$ & $251(23.1 \%)$ & 0.7294 & $1(4.2 \%)$ & $55(8.6 \%)$ & 0.7123 \\
\hline Fetal blood analysis (n, \%) & $3(4.0 \%)$ & $39(3.6 \%)$ & 0.7486 & 0 & $1(0.2 \%)$ & 1.0000 \\
\hline Epidural anaesthesia (n, \%) & $33(44.0 \%)$ & $654(60.4 \%)$ & 0.0050 & $4(16.7 \%)$ & $145(22.8 \%)$ & 0.4806 \\
\hline Oxytocin $(\mathrm{n}, \%)$ & $31(41.9 \%)$ & $595(55.9 \%)$ & 0.0195 & $3(12.5 \%)$ & $122(19.3 \%)$ & 0.5966 \\
\hline Meconium-stained amniotic liquor (n, \%) & $14(18.7 \%)$ & $237(21.8 \%)$ & 0.5257 & $312.5 \%)$ & $67(10.5 \%)$ & 0.7332 \\
\hline $\begin{array}{l}\text { Chorioamnionitis }(\mathrm{n}, \%) \\
\text { care unit, total }(\mathrm{n}, \%)\end{array}$ & $1(1.3 \%)$ & $10(0.9 \%)$ & 0.5212 & 0 & 0 & n. c. \\
\hline Postpartum transfer to neonatal & $19(25.3 \%)$ & $201(18.5 \%)$ & 0.1424 & $4(16.7 \%)$ & $67(10.5 \%)$ & 0.3141 \\
\hline Infection of the newborn (n, \%) & $4(5.3 \%)$ & $69(6.3 \%)$ & 1.0000 & 0 & $18(2.8 \$)$ & 1.0000 \\
\hline
\end{tabular}

BE: Base excess; n.c.: not calculable. $p<0.05$ was considered significant. *Cesarean sections and failed induction of labor are excluded. **Cesarean sections are excluded.

$29.6 \pm 5.9, p=0.0011)$ compared to the "no preeclampsia" group. Furthermore, labor was induced earlier $(272.5 \pm 8.3$ days of gestation $v s .283 .8 \pm 8.0$ days of gestation, $p<0.0001$ ) and birth weight was lower $(3197.5 \pm 483.7$ grams $v s$. $3392.9 \pm 499.6$ grams, $p<0.0001)$ in the preeclampsia group. The Bishop score in the preeclampsia group was lower [median $=1(0-1)$ vs. median $=2(0-10), p=0.0088]$. The proportions relating to the methods for induction of labor were similar except for dinoproston use where a higher rate has been observed in the preeclampsia group $(19.2 \% \mathrm{vs}$. $9.3 \%, p=0.0013)$. The majority of patients in the control group was induced because of pregnancy at or beyond 41 weeks of gestation $(52.6 \%)$, followed by induction on request $(12.4 \%)$ and gestational diabetes $(8.2 \%)$.

The pooled outcome parameters are given in Table II. The cesarean section rate, which was the primary outcome measure, was significantly higher in the preeclampsia group (32.3\% vs. 22.2\%, $p=0.0189$ ). Moreover, in the preeclampsia group, the induction-to-delivery interval was longer [median $1912(255-4237) v s .1575$ (97-4318) $\mathrm{min}, p=0.0051]$ and the vaginal birth rates within $24 \mathrm{~h}(24.6 \%$ vs. $31.1 \%, p=0.0226)$ and $48 \mathrm{~h}(67.2 \%$ vs. $83.1 \%, p=0.0015)$ were lower. Newborns had to be transferred to the neonatal care unit more often when labor was induced for preeclampsia $(23.2 \%$ vs. $15.6 \%, p=0.0423$ ).

The outcome parameters according to parity are demonstrated in Table III. When considering the parity, the cesarean section rate was not significantly different in nulliparous (37.3\% vs. $31.7 \%, p=0.3129)$ between women with and without preclampsia; in parous women, however, the difference between these two groups (16.7\% vs. $5.8 \%$, $p=0.0550)$ just barely failed to reach significance.

In nulliparous women, the induction-to-delivery interval was longer in the preeclampsia group [2261 (582-4237) vs. $1767(288-4318) \min , p=0.0111)$, and the rate of vaginal deliveries within $48 \mathrm{~h}(57.1 \%$ vs. $79.9 \%, p=0.0005)$ was lower. Oxytocin was administered more often when there was no preeclampsia present $(41.9 \%$ vs. $55.9 \%, p=0.0195)$. The epidural anaesthesia rate was lower in women with preeclampsia $(44.0 \%$ vs. $60.4 \%, p=0.0050)$. 
in vivo $34: 1195-1200(2020)$

Table IV. Univariable and multiple Logistic regression analysis of the primary outcome measure cesarean section rate.

\begin{tabular}{|c|c|c|c|c|}
\hline & $\begin{array}{l}\text { Univariable analysis } \\
\text { Odds ratio }\end{array}$ & $\begin{array}{l}\text { Univariable analysis } \\
\quad(p \text {-Value })\end{array}$ & $\begin{array}{l}\text { Multiple analysis } \\
\text { Odds ratio }\end{array}$ & $\begin{array}{l}\text { Multiple analysis } \\
\text { significant } p \text {-Value }\end{array}$ \\
\hline Preeclampsia & 1.679 & 0.0199 & & \\
\hline Body mass index $\left(\mathrm{kg} / \mathrm{m}^{2}\right)$ & 1.063 & $<0.0001$ & 1.066 & $<0.0001$ \\
\hline Age (years) & 1.018 & 0.1013 & & \\
\hline Parity & 0.248 & $<0.0001$ & 0.263 & $<0.0001$ \\
\hline Gestational age (days) & 1.008 & 0.2248 & & \\
\hline Birth weight $(\mathrm{kg})$ & 1.114 & 0.3347 & & \\
\hline Bishop score & 0.811 & $<0.0001$ & 0.893 & 0.0036 \\
\hline (Gestational) diabetes & 1.302 & 0.0786 & & \\
\hline Fetal growth restriction & 0.902 & 0.6628 & & \\
\hline \multicolumn{5}{|l|}{ Indication for induction of labour } \\
\hline Pregnancy at or beyond 41 weeks & 1.016 & 0.8889 & & \\
\hline Gestational diabetes & 0.999 & 0.9965 & & \\
\hline On request & 0.733 & 0.0967 & & \\
\hline Anhydramnios/Oligohydramnios & 0.718 & 0.1914 & & \\
\hline Suspected fetal macrosomia & 2.307 & 0.0266 & 2.888 & 0.0162 \\
\hline Less fetal movements & 0.850 & 0.8850 & & \\
\hline $\begin{array}{l}\text { Fetal growth restriction; placental insufficiency; } \\
\text { abnormal Doppler }\end{array}$ & 0.644 & 0.0668 & & \\
\hline Preeclampsia, hypertensive disorders & 1.751 & 0.0016 & & \\
\hline Abnormal CTG & 0.972 & 0.9518 & & \\
\hline Intrahepatic cholestasis in pregnancy & 0.321 & 0.1257 & & \\
\hline Other & 1.471 & 0.1572 & & \\
\hline
\end{tabular}

Ctg: Cardiotocogram, kg: kilogram.

In parous women, no statistically significant differences between the preeclampsia group and the control group could be found.

The results of logistic regression analysis for the outcome measures "cesarean section" are shown in Table IV. In the multiple model, BMI, parity, and Bishop score remained significant. High BMI increased the cesarean section rate whereas high parity and high Bishop score decreased it. Concerning the indication for induction of labor, only a suspected fetal macrosomia was relevant and increased the cesarean section rate. Remarkably, the presence of preeclampsia is not significantly associated with the cesarean section rate. This finding suggests that preeclampsia does not affect causally the outcome. The significant test result in the univariable analysis ( $p=0.0189$, Table II) is due to different baseline characeristics. According to the $p$-Values resulting from the multiple logistic regression analysis, high BMI and low parity (not preeclampsia) seem to be the most important risk factors for cesarean section.

\section{Discussion}

This study compared the induction of labor for preeclampsia with labor inductions for other reasons. The analysis of data (especially the multiple regression analysis) could demonstrate that induction of labor for preeclampsia is not associated with a higher cesarean section rate but with a longer induction-to-delivery interval and less births within $48 \mathrm{~h}$ after induction in nulliparous women.

Induction of labor is more frequent in women with preeclampsia and eclampsia (2). Success of induction depends on gestational age and is reported to be higher in pregnancies after 32 weeks of gestation (7). It has been demonstrated that after 32 weeks of gestation the vaginal delivery rate after induction of labor ranges around 62.5$68.8 \%$ in patients with preeclampsia $(6-8,13)$.

In the present study, we could not find a higher cesarean section rate following induction of labor for preeclampsia after having adjusted for BMI and parity. These results confirm the findings of Bernardes et al. who has shown that induction of labor is not associated with increased rates of cesarean section or adverse neonatal outcome in pregnancies between 36 and 41 weeks of gestation with gestational hypertension or mild preeclampsia compared to expectative management, even in patients with an unripe cervix (Bishop score $<6)(14)$. In contrast to these findings, in another retrospective analysis nulliparous and parous women had higher cesarean section rates compared to women without preeclampsia (30\% vs. 23\%, $p=0.011)$ (15). These results could be explained by inclusion of patients in early weeks of gestation as the success of vaginal delivery is described to be lower at those stages (7). In contrast to our results, 
Thrornton et al. have shown in a retrospective analysis that induction of labor (rather than spontaneous labor) in women with preeclampsia or superimposed preeclampsia leads to lower rates of vaginal delivery than spontaneous labor compared to women without a hypertensive disorder during pregnancy (16).

Induction of labor was not associated with an increase in neonatal morbidity or mortality (7). It has been shown that induction of labor is associated with decreased risks of neonatal complications (any of the following three: i) 5-min Apgar score less than 5, ii) arterial cord $\mathrm{pH}$ less than 7.0, or iii) the clinical diagnoses of asphyxia or hypoxic-ischemic encephalopathy), NICU admission and respiratory distress syndrome compared to planned cesarean delivery in patients with mild, severe or superimposed preeclampsia $>34+0$ weeks of gestation. Furthermore, induction of labor has not been associated with an increased risk of the maternal outcome parameters (hysterectomy, transfusion, ICU admission, deep venous thrombosis, and pulmonary embolism) compared to planned cesarean delivery (13).

In our study we could not demonstrate a significant difference in the maternal outcome parameters following induction of labor in women with preeclampsia. Interestingly, it has been previously demonstrated that women with preeclampsia having a cesarean section have a significantly higher severe maternal morbidity rate following caeserean section (54.0 vs. 32.7\%) (6). A randomized controlled trial with women between $36+0$ and $41+0$ weeks of gestation with gestational hypertension or mild preeclampsia has also demonstrated that induction of labor is associated with an improved maternal outcome compared to expectative management, without increasing the cesarean section rate (3). These results mentioned above are in line with our findings as we could not find any differences concerning maternal and fetal outcome parameters in women with preeclampsia who's labor was induced in comparison to labor induction because of other indications.

This study has some limitations and some strengths. The main limitation is its retrospective nature of data collection. Furthermore, the two groups differed significantly from one another with regard to certain factors. Women in the preeclampsia group had a higher weight, BMI and gestational age as well as a lower Bishop score and birth weight. These factors, especially high BMI and low Bishop score, are well known to be risk factors for failed induction. However, the impact of these factors has been controlled by a multivariable analysis. Since there was no difference regarding the cesarean section rate between the two groups when stratifiying for parity and BMI, the safety of labor induction in preeclamptic women can be underlined. The stratification for parity is a main strength of this investigation. In most of the previous investigations, there was no stratification for parity which may result in counterfactual conclusions. When only considering our pooled data, one might conclude that there was a different cesarean section rate between the two groups.

In conclusion, labor induction in patients with preeclampsia did not influence the cesarean section rate in nulliparous and parous women at term.

\section{Conflicts of Interest}

No conflicts of interest to declare.

\section{Authors' Contributions}

JP contributed to acquisition of data and was a major contributor in writing the article. CW contributed analysis and interpretation of data. UD and FS contributetd to aquisition of data and were involved in revising the article critically. FF involved in revising the article critically. MWB revised the article critically and gave final approval of the version to be published. SK contributed to aquisition of data, conception and design and gave final approval of the version to be published. All Authors read and approved the final article.

\section{References}

1 Duley L: The global impact of pre-eclampsia and eclampsia. Semin Perinatol 33(3): 130-137, 2009. PMID: 19464502. DOI: 10.1053/j.semperi.2009.02.010

2 Abalos E, Cuesta C, Carroli G, Qureshi Z, Widmer M, Vogel JP, Souza JP, Maternal WHOMSo and Newborn Health Research N: Pre-eclampsia, eclampsia and adverse maternal and perinatal outcomes: A secondary analysis of the world health organization multicountry survey on maternal and newborn health. BJOG 121 Suppl 1: 14-24, 2014. PMID: 24641531. DOI: 10.1111/14710528.12629

3 Koopmans CM, Bijlenga D, Groen H, Vijgen SM, Aarnoudse JG, Bekedam DJ, van den Berg PP, de Boer K, Burggraaff JM, Bloemenkamp KW, Drogtrop AP, Franx A, de Groot CJ, Huisjes AJ, Kwee A, van Loon AJ, Lub A, Papatsonis DN, van der Post JA, Roumen FJ, Scheepers HC, Willekes C, Mol BW, van Pampus MG and HYPITAT study group: Induction of labour versus expectant monitoring for gestational hypertension or mild pre-eclampsia after 36 weeks' gestation (hypitat): A multicentre, open-label randomised controlled trial. Lancet 374(9694): 979-988, 2009. PMID: 19656558. DOI: 10.1016/S0140-6736(09)60736-4

4 Stepan H, Kuse-Fohl S, Klockenbusch W, Rath W, Schauf B, Walther $\mathrm{T}$ and Schlembach D: Diagnosis and treatment of hypertensive pregnancy disorders. Guideline of dggg (s1-level, awmf registry no. 015/018, december 2013). Geburtshilfe Frauenheilkd 75(9): 900-914, 2015. PMID: 5396549. DOI: 10.1055/s-0035-1557924

5 Kehl S, Dotsch J, Hecher K, Schlembach D, Schmitz D, Stepan $\mathrm{H}$ and Gembruch $\mathrm{U}$ : Intrauterine growth restriction. Guideline of the german society of gynecology and obstetrics (s2k-level, awmf registry no. 015/080, october 2016). Geburtshilfe Frauenheilkd 77(11): 1157-1173, 2017. PMID: 5784232. DOI: 10.1055/s-0043-118908 
6 Amorim MM, Katz L, Barros AS, Almeida TS, Souza AS and Faundes A: Maternal outcomes according to mode of delivery in women with severe preeclampsia: A cohort study. J Matern Fetal Neonatal Med 28(6): 654-660, 2015. PMID: 24866351. DOI: $10.3109 / 14767058.2014 .928689$

7 Alanis MC, Robinson CJ, Hulsey TC, Ebeling M and Johnson DD: Early-onset severe preeclampsia: Induction of labor $v s$ elective cesarean delivery and neonatal outcomes. Am J Obstet Gynecol 199(3): 262 e261-266, 2008. PMID: 18771976. DOI: 10.1016/j.ajog.2008.06.076

8 Nassar AH, Adra AM, Chakhtoura N, Gomez-Marin O and Beydoun S: Severe preeclampsia remote from term: Labor induction or elective cesarean delivery? Am J Obstet Gynecol 179(5): 1210-1213, 1998. PMID: 9822502. DOI: 10.1016/s00029378(98)70133-4

9 Report of the national high blood pressure education program working group on high blood pressure in pregnancy. Am J Obstet Gynecol 183(1): S1-S22, 2000. PMID: 10920346.

10 Kehl S, Weiss C, Dammer U, Baier F, Faschingbauer F, Beckmann MW, Sutterlin M and Pretscher J: Effect of premature rupture of membranes on induction of labor: A historical cohort study. Geburtshilfe Frauenheilkd 77(11): 1174-1181, 2017. PMID: 5703656. DOI: $10.1055 / \mathrm{s}-0043-121007$

11 Rempen A, Chaoui R, Hausler M, Kagan KO, Kozlowski P, von Kaisenberg C and Wisser J: Quality requirements for ultrasound examination in early pregnancy (degum level i) between $4+0$ and 13+6 weeks of gestation. Ultraschall Med 37(6): 579-583, 2016. PMID: 27626239. DOI: $10.1055 / \mathrm{s}-0042-115581$

12 Bishop EH: Pelvic scoring for elective induction. Obstet Gynecol 24(266-268, 1964. PMID: 14199536.
13 Kawakita T and Bowers K: Maternal and neonatal outcomes of induction of labor compared with planned cesarean delivery in women with preeclampsia at 34 weeks' gestation or longer. Am J Perinatol 35(1): 95-102, 2018. PMID: 28838008. DOI: $10.1055 / \mathrm{s}-0037-1606185$

14 Bernardes TP, Broekhuijsen K, Koopmans CM, Boers KE, van Wyk L, Tajik P, van Pampus MG, Scherjon SA, Mol BW, Franssen MT, van den Berg PP and Groen H: Caesarean section rates and adverse neonatal outcomes after induction of labour versus expectant management in women with an unripe cervix: A secondary analysis of the hypitat and digitat trials. BJOG 123(9): 1501-1508, 2016. PMID: 27173131. DOI: 10.1111/14710528.14028

15 Kim LH, Cheng YW, Delaney S, Jelin AC and Caughey AB: Is preeclampsia associated with an increased risk of cesarean delivery if labor is induced? J Matern Fetal Neonatal Med 23(5): 383-388, 2010. PMID: 19951010. DOI: 10.3109/1476705090 3168432

16 Thornton CE, Dahlen HG and Hennessy A: Does induction of labour in nulliparous hypertensive women result in vaginal birth? A descriptive study utilising birth registry data. Pregnancy Hypertens 12: 16-22, 2018. PMID: 29674193. DOI: 10.1016/j. preghy.2018.01.010

Received December 5, 2019

Revised January 22, 2020

Accepted January 27, 2020 